\title{
THE STUDY OF OLD TESTAMENT THEOLOGY: ITS AIMS AND PURPOSE*
}

\author{
By J. GOLDINGAY
}

The history of Old Testament theology as a discipline has been well chronicled, for instance (from varying perspectives) by N.W. Porteous, R.C. Dentan, R.K. Harrison, and W.F. Harrington. ${ }^{1}$ Its floruit began, in the context of renewed German theological interest in the Bible between the wars, with the publication of Eichrodt's first volume in 1933. ${ }^{2}$ It ended with the publication in Germany in 1960 of von Rad's second volume. ${ }^{3}$ Von Rad's work has introduced a period of reflection and debate - a debate which continues without seeming to promise early agreed conclusions - upon the methodology of Old Testament Theology. ${ }^{4}$ In part this was because von Rad's diachronic approach was so radically different from the one that had broadly characterized the earlier Old Testament Theologies. ${ }^{5}$ But to this fact must be added the broader questions being asked about the Old

*A paper read at a meeting of the Tyndale Fellowship at Tyndale House, Cambridge, in July, 1974.

1 N.W. Porteous, 'Old Testament Theology', in The Old Testament and Modern Study (ed. H.H. Rowley), O.U.P., London (1951); R.C. Dentan, Preface to Old Testament Theology, Seabury Press, New York (revised 1963); R.K. Harrison, Introduction to the Old Testament, Tyndale Press, London (1970); W.F. Harrington. The Path of Biblical Theology, Gill and Macmillan, Dublin (1973).

W. Eichrodt, Theologie des Alten Testaments, Teil I, Leipzig (1933).

(E.T. Theology of the Old Testament, Volume I (Old Testament Library), S.C.M. Press, London, 1961). The remaining two volumes were published in 1935 and 1939 (E.T. as Volume II, 1961).

3 G. von Rad, Theologie des Alten Testaments, Band II, Chr. Kaiser Verlag, Munich (1960). (E.T. Old Testament Theology Volume II, Oliver and Boyd, Edinburgh, 1965). The first volume was published in 1957 (E.T. 1962).

${ }^{4}$ See G.F. Hasel, 'Methodology as a major problem in the current crisis of Old Testament theology', Biblical Theology Bulletin 2:2 (1972) 177-198; Old Testament Theology: Basic Issues in the Current Debate Eerdmans, Grand Rapids (1972).

5 For the distinction between the 'diachronic' approach of von $\mathrm{Rad}$, who 
Testament's significance, reflected in the two volumes of essays by Claus Westermann and B.W. Anderson ${ }^{6}-$ and also the wider debate on hermeneutics. There have been other contributory factors, notably the varied broadsides of James Barr upon loose thinking especially in this area, beginning in 1961 with The Semantics of Biblical Language ${ }^{7}$ and the publication of Honest to God $(1963)^{8}$ and The Secular City (1965), ${ }^{9}$ which Brevard Childs sees as bringing to a head the American 'Crisis in Biblical Theology' - this was, he reckons, the moment when the American postwar 'biblical theology movement' died and creative theology resumed a more 'natural' or philosophical turn. ${ }^{10}$ We have thus entered a period of reflection, and hesitation about the task of writing Old Testament theology.

This paper takes up three aspects of the study of Old Testament theology and interpretation. The first is the question of presuppositions: can Old Testament theology be presuppositionless and uninvolved? Is its task only descriptive ("this was the Old Testament faith") or should it aim to make clear what must be believed today by someone who regards himself as the spiritual son of the Old Testament? The second section considers the relationship between Old Testament theology and New Testament theology in the context of biblical theology, and asks whether the last is the discipline that really counts, whereas the former are both rather odd truncated affairs. The third section asks what is the raison d'être of theology, and therefore of Old Testament theology, and suggests that its primary function is to be an aid in the exposition of Scripture.

writes a historical theology of the Old Testament, and the 'synchronic' approach of Eichrodt and others who offer a 'cross-section' of the Old Testament faith, see J. Harvey 'The new diachronic biblical theology of the Old Testament', Biblical Theology Bulletin 1:1 (1970) 5-29.

6 C. Westermann (ed.), Essays on Old Testament Interpretation, S.C.M. Press, London (1963) (also published as Essays on Old Testament Hermeneutics) (E.T. of Probleme Alttestamentliche Hermeneutik, Chr. Kaiser Verlag, Munich, 1960); B.W. Anderson (ed.) The Old Testament and Christian Faith, S.C.M. Press, London (1964).

7 O.U.P., London; also Biblical Words for Time (Studies in Biblical Theology 1.33), S.C.M. Press, London (1962, revised 1969); Old and New in Interpretation, S.C.M. Press, London (1966); The Bible in the Modern World,

S.C.M. Press, London (1973).

8 J.A.T. Robinson, Honest to God, S.C.M. Press, London (1963).

9 Harvey Cox, The Secular City, S.C.M. Press, London (1965).

10 B.S. Childs, Biblical Theology in Crisis, Westminster Press, Philadelphia (1970), pp. 85-87. 
1. How are we to ascertain the Old Testament's theology?

At its most naive (as we can now see it), the study of the history of Israel's religion - which was the nearest most people got to. Old Testament theology between the rise of modern criticism and the 1930's, or even after - supposed itself to be a presuppositionless, detached, and descriptive historical/scientific exercise. The presuppositions it actually held - evolutionism, rationalism, and so on - are now only too clear to us; and it is widely recognized that in reality noone can involve himself in presuppositionless study. The student rather needs to be able first to recognize and acknowledge what his presuppositions are and then to see at what point the material he is studying bursts their bounds and corrects the perspective with which he approached it. It is in fact characteristic of the modern Old Testament theologies that they acknowledge their Christian perspective and consciously allow it to affect the material's presentation. Thus Eichrodt describes Old Testament theology's concern as to obtain "a comprehensive picture of the realm of Old Testament belief" but also "to see that this comprehensive picture does justice to the essential relationship with the New Testament". ${ }^{11}$

Inevitably, perhaps, writers do not always succeed in recognizing when the material bursts the bounds of the presuppositions. For instance, within the context of the Old Testament cultic worship has an important theological place.

'Cult or ritual may be defined as the socially established and regulated holy acts and words in which the encounter and communion of the Deity with the congregation is established, developed, and brought to its ultimate goal. In other words: a relation in which a religion becomes a vitalizing function as a communion of God and congregation, and of the members of the congregation among themselves.'

Mowinckel's definition ${ }^{12}$ indicates the role of worship in the Old Testament as it is suggested in particular by Genesis to Numbers, Chronicles, and Psalms. But many protestant Old Testament exegetes, of whom Wellhausen was the classic

11 Theology, I, 27.

12 S. Mowinckel, The Psalms in Israel's Worship, Blackwell, Oxford (1967), Volume I, 15. 
example, have had a predominantly negative view of the cult, a value judgment derived not from the New Testament but from a particular strand of Christianity.

It is, of course, always easier to recognize how someone else's presuppositions vitiate his interpretation, than it is to see the same process at work in one's own efforts. One of the important reasons for studying the work of those who start from different bases is to see whether there are elements in the material that they are doing justice to in a way one is not oneself. For instance, modern Jewish theology inevitably asks questions about the theological significance of the land of Israel. ${ }^{13}$ This reminds one of the importance of the land as a theme in the Old Testament. ${ }^{14}$ But this theme receives little treatment in the Christian Old Testament theologies, ${ }^{15}$ perhaps because of the desacralizing of the land under the new covenant. But any Old Testament theology written from Christian presuppositions needs to be able to embrace all the Old Testament's theological themes. There is scope for dialogue here as to whose presuppositions provide the most satisfactory context for interpreting the Old Testament: whether, for instance, Jewish ones do this better than Christian ones, or Bultmann's than those of more conservative scholars. And even if the latter are broadly right, our understanding of the biblical Christian approach may need correcting in the light of the contents of the Old Testament material itself.

The earlier critical biblical study further professed to avoid involvement, as well as to be presuppositionless. Eissfeldt, in a famous article in Zeitschrift für die alttestamentliche Wissenschaft, seems according to Porteous ${ }^{16}$ to have regarded the assertion "that no historical document would disclose its meaning except to someone who had an inner understanding

\footnotetext{
13 See for instance, E.B. Borowitz 'The problem of the form of a Jewish theology', HUCA 40-41 (1969-70) 391-408.

$14 C f$. (as far as the hexateuch is concerned) G. von Rad, 'The promised land and Yahweh's land in the hexateuch', in The Problem of the Hexateuch and other essays, Oliver and Boyd, Edinburgh (1966).

5 'Though see G.A.F. Knight, $A$ Christian Theology of the Old Testament, S.C.M. Press, London (1959, $\left.{ }^{2} 1964\right)$, chapter 25: 6-7; also W.D. Davies, The Gospel and the Land (University of California, 1974).

16 Op. cit., 320; the reference is to 0 . Eissfeldt, 'Israelitisch-judische

Religionsgeschichte und alttestamentliche Theologie', ZAW 44 (1926) 1-12.
} 
of it and a certain affection for it and that similarly an inner understanding is necessary for the proper appreciation of the meaning of the Bible" as a "tampering with historical objectivity".

Again, however, it is now widely seen that the method of study in any discipline must match the object of study. A faith - any faith - cannot be studied with 'scientific' detachment. The observer, in order to appreciate, has to allow himself a certain involvement, an empathy - a feeling into what one does not (necessarily) actually share. "We must learn to live in the atmosphere of the Old Testament". "This religion, like any other, can be understood only from within, or through a sympathy that makes us its 'resident aliens' (gerim)."17

The strength of the diachronic approach to Old Testament theology ${ }^{18}$ is that it better facilitates a 'feeling into' being an Israelite believer. The 'cross-section' approach ${ }^{19}$ is inevitably more abstract, the synthesis more synthetic, and less able to convey the impact of what God meant to Israel, and how she responded to him, in the concrete situations of life.

Like any empathy, however, this is a 'feeling into' the object which does not necessarily mean you have to identify with it. It is not the case that a faith can only be understood by someone who shares it - otherwise no-one could understand any other faith. But he does have to become a resident alien.

A third characteristic of the older study of Israel's faith was its purely descriptive nature. Its aim was just to investigate what was believed, not to extrapolate as to what should be believed. This feature too is now widely questioned, though the debate is a confused one.

One reason for this questioning, and for the assertion that Old Testament theology must be normative, not just descriptive, is really only an extension of the point we have just considered, that is that an Old Testament theologian must be involved - he must seek to get inside his subject, to be a vicarious Israelite. Porteous ${ }^{20}$ seems to equate this with an

${ }^{17}$ H.W. Robinson, Inspiration and Revelation in the Old Testament, O.U.P., London (1946) 281-2.

${ }^{18}$ Notably von Rad's Theology; also E. Voegelin, Order in History I: Israel and Revelation, Louisiana State University Press, Baton Rouge (1956); G. Vos, Biblical Theology, Eerdmans, Grand Rapids (1948); W. Zimmerli, Man and his Hope in the Old Testament (Studies in Biblical Theology II.20), S.C.M. Press, London (1971).

${ }^{19}$ Cf. Eichrodt, Theology I, p.27. 
attempt to write 'normative' Christian Old Testament theology; but the two aims are surely distinguishable. One may indeed grant, following modern hermeneutical theory, that the significance of a text from an alien culture is only truly appreciated when one has gone on to re-express what it was saying in the terms of one's own culture. ${ }^{21}$ In other words, writing normative Old Testament theology - expressing what the Old Testament faith means now - is a means to appreciating what it meant in Old Testament times. But this does not alter the fact that there is a difference between the statement of Old Testament faith in its terms, according to its interests, in its context, and the restatement of it in our terms, according to our interests, in our context. Although these are interrelated, they are distinguishable.

Now such restatement of the faith is surely the task of dogmatic theology. Biblical theology seeks to express the content of the biblical faith, its structure and its component parts in their dynamic interrelationship, in the Bible's own terms and according to its priorities. Biblical theology is a descriptive study like Buddhist theology or Jewish theology or whatever. It is dogmatic theology's role to go on to re-express the biblical faith in contemporary categories and to see how it interracts with the approaches and concerns and assumptions of the contemporary world. It is dogmatic theology that is confessional and that leads to the appropriation of that reality to which it refers. ${ }^{22}$ It is dogmatic theology that has to be written and read on one's knees. Biblical theology is the handmaid of biblical exegesis, dogmatic theology of biblical exposition. When exegesis or biblical theology warms the heart, that is an uncovenanted mercy, or a sign that they are becoming exposition or dogmatics.

Of course, dogmatics may look elsewhere for its raw material; for instance, John Macquarrie ${ }^{\mathbf{2 3}}$ enumerates the 'formative factors' of his theology as experience, revelation, scripture,

${ }^{20}$ Op. cit., $317-22,343-4$; the point is also made in his essays collected in Living the Mystery, Blackwell, Oxford (1967) e.g. 22-24. 329-31.

See, for instance, G. Ebeling, Word and Faith, S.C.M. Press, London (1963)

${ }^{22} C f$. Barth's description of the goal of interpretation in Church Dogmatics, I, The Doctrine of the Word of God 2, T. \& T. Clark, Edinburgh (1956) 19.1; 21.2; especially pp. 736-40.

${ }^{23}$ Principles of Christian Theology, S.C.M. Press, London (1966) 4-17. 
tradition, culture, and reason. Or it may use biblical theology only within the framework of a non-negotiable external perspective such as the magisterium. ${ }^{24}$ An evangelical dogmatic theology will be a systematic restatement of the biblical faith in the terms of today, with a perspective that is always subject to correction in the light of the Bible itself. Yet to call this 'biblical theology' is confusing; and it surrenders the discipline 'dogmatic theology' to theologians who would not subscribe to a biblical approach - which presumably evangelical dogmatic theologians would not want to do. It has also led to the devaluing of the idea of 'biblical theology', as this description has been claimed by various conflicting systems.

Nevertheless one must grant the importance of what is being emphasised by those who wish to speak in 'normative biblical theology' terms. The biblical and the dogmatic theologian must engage in dialogue to ensure that the latter does take up where the former leaves off. The dogmatist may need to come back to the biblical theologian with sharper questions - or may want to indulge in biblical theology himself; the biblical theologian may not remain silent when he sees biblical emphases being neglected, and may want to go on to reexpress them himself. But the disciplines need to be seen as separate ones. Descriptive biblical theology needs to keep its independence. As Stendahl puts it in his classic modern restatement of the 'descriptive' viewpoint, "when the biblical theologian becomes primarily concerned with the present meaning, he ... loses his enthusiasm for the descriptive task" 25 as the interpreter who is too concerned with exposition tends to skip exegesis.

\section{Old Testament Theology in the Context of Biblical Theology Theology}

But what is the point of Old Testament Theology? If it is biblical theology that provides the raw material for our restate-

${ }^{24} C f$. K. Rahner, 'Scripture and Theology', in Theological Investigations VI, Helicon Press, Baltimore, Darton, Longman and Todd, London (1969) 96

${ }^{25} \mathrm{~K}$. Stendahl, 'Biblical theology, contemporary', in G.A. Buttrick (ed.) The Interpreter's Dictionary of the Bible, Abingdon Press, New York and Nashville (1962) Volume I, 421b. 
ment of the faith today, why try to systematize, to crosssection, the Old Testament independently of the Bible as a whole?

The possibility of a Christian Old Testament theology depends on the assumption that the cross-section of Old Testament faith is the same as that of the New Testament - God is the same, man is the same, and in principle the ba sis upon which God and man relate is the same (God's grace, his revealing his will, his providing means of reconciliation with sinful man, and so on, along with the corresponding human responses to these initiatives). Eichrodt, in fact, states it as the purpose of his synthesis to make it possible to compare Old Testament faith with that of the New Testament. ${ }^{26}$ And the existence of 'Old Testament theologies' may help to prevent the Old Testament's voice being lost.

They also have the practical value of enabling us to set particular passages or ideas of the Old Testament into the theological context which (we will presumably claim) was implicit in the thinking of the writer. Our knowledge of the parts is enhanced by our knowledge of the whole. But perhaps the fundamental reason for trying to synthesize this Old Testament faith is like that for climbing Everest - it's there. There is an intellectual satisfaction in grasping the total structure of Old Testament faith.

And yet, Old Testament theology remains in a sense an odd affair. Alec Motyer remarks that, if you want to understand the relationship between the testaments, the first thing to do is tear out the blank page in your Bible between Malachi and Matthew. Such an assertion implies that the discontinuity which separates the salvation events of A.D. from those of B.C. is no sharper than the one which separates from each other the salvation events within the B.C. period (call of Abraham, exodus and conquest, monarchy and temple building, exile and restoration, and so on); that there is no sharper distinction between the New Testament and the Old Testament than there is between the Torah and the Prophets, or the Prophets and the Writings. Now an Old Testament theology that incorporated only the insights of (for instance) the pre-exilic period would be unbalanced. It would still be an interesting exercise in historical theology,

${ }^{26}$ Theology I 27-31. 
it would still help to provide a wider context for understanding individual pre-exilic passages; but we could not know what place these had in a total picture of God's truth until we considered the thought of later periods.

And surely the same is true of Old Testament theology as a whole. If the Old Testament is only Act 1 to the New Testament's Act $2^{27}$ - or even Acts 1-3 to the New Testament's Act 4 ! - who would dream of assessing the mind of the dramatist on the basis of Act 1 only? It is the boundaries of the total canon that mark the area within which God has revealed his truth in scripture, and our grasp of that truth will be at least incomplete, if not distorted, if we fence off one area and try to generalize about the rest in isolation.

An example will be in order. Most of the biblical material for a doctrine of creation comes from the Old Testament. It shows us how God's creation is purposeful and systematic and aesthetic (Gen. 1), how man is its climax (Gen. 1) or centre (Gen. 2), how it continues in his providing for the world (Ps. 104), how it proves his lordship and authority to act in history and salvation (Is. 40), how it evidences his love and power when we are tempted to doubt them (Job 38-41), how it sets us an example of the use of the mind, of wisdom (Prov. 8 ), and so on. But the full breadth of the biblical treatment of this doctrine is not appreciated without also taking into account the New Testament's assertion that the Christ, through whom the world is redeemed, is also the one through whom God both created it (Jn. 1) and sustains it (Col. 1).

The Old Testament's witness needs to be completed by that of the New. This is not to say that the former is unclear or misleading; it is just not all that has been said. Admittedly the omission of the climatic salvation act of God is most likely to unbalance our picture of God's purpose. And yet even where the New Testament is often regarded as a 'step forward' in relation to the theological or moral 'primitiveness' of the Old Testament, the tension between 'primitive' and 'advanced' - or rather, perhaps, between 'ideal' and 'realistic' - is there in the Old Testament itself. For instance, the interiorization of the moral demands of God does not begin in the Sermon on the Mount: although much of Old Testament law

27 J. Bright, The Authority of the Old Testament, S.C.M. Press, London (1967) 202. 
is concerned with outward actions, in the decalogue the verb for 'to covet' in Exodus 20, hämad, probably indicates an attitude of mind as well as "an activity, almost equivalent to 'seeking to acquire"", ${ }^{28}$ while the form in Deuteronomy 5 adds the verb hit'awwäh which unambiguously refers to a feeling of desire ${ }^{29}$ and, if the attitude to be shown to God is expressed in the decalogue only in negative terms, in Deuteronomy 6 the positive is stressed - love, fear, serve, swear by, obey. Further, the proof that Old Testament divorce laws were given only because of Israel's hardness of heart lies not in a deeper revelation that Christ brings, but in the nature of the oldest revelation (see Mk. 10: 2-9). Again, the idea of resurrection appears at least in Daniel 12, even though this stands in contrast to the rest of the Old Testament. What the New Testament brings is not revelation of new truth but a new event (which incarnates the truth of the old revelation), and thus a new possibility of achieving the old revelation's ideal.

Nevertheless, it is not the case that Old Testament events were somehow not 'for real' but happened solely to hint (and only in an unintelligible way) at the one great future event that counted. The events in Israel's history do need to be seen in the light of the incarnation if we are fully to understand their significance in God's purpose; but we must not slip into suggesting (as some concepts of typology do) that they were only pre-figurations without real meaning at the time.

Nor, therefore, are we to read back the New Testament into the Old. Our biblical (and therefore dogmatic) doctrine of creation should be Christological; but our exegesis of Genesis 1 will not be.

But the New Testament will sometimes provide us with a clue, as it does in the above cases, for interpreting the diversity of the Old Testament's witness. The Old Testament manifests both universalism and nationalism, both a stress on grace and what could be construed as moralism, both a profound grasp of human sinfulness and a challenge to human responsibility which suggests that obedience is possible. How are these to

28 R.A. Colẹ, Exodus (Tyndale Old Testament Commentaries), Tyndale Press, London (1973) in loc.

${ }^{29} C f$. Childs, Exodus (Old Testament Library), S.C.M. Press, London (1974) in loc. 
be related? Judaism stressed the latter of each pair ${ }^{30}$ and it may not be possible to prove it was wrong except by setting alongside the Jewish interpretation of the Old Testament a Christian one in which the Old Testament is understood not in the light of the rabbis but in the light of the New Testament, which provides not only extra data but also a key to a satisfying interpretation of the data as a whole.

But the converse also applies: New Testament theology must be read in the light of that of the Old. This is obviously true in the sense that the Old Testament provides necessary background to understanding terms such as 'Son of Man', and more broadly in the sense that the Old Testament tells us the question to which the New Testament is the answer. ${ }^{31}$ Yet in these two respects the Old Testament is not unique: intertestamental Jewish thought is also important here, arguably more so if it is the Old Testament faith as currently re-expressed (or should we say, rather, transformed?) in Judaism, not the Old Testament faith itself, that is the direct background to New Testament thinking.

More importantly, in the context of the existence of the canon, New Testament theology cannot stand alone as a balanced guide to biblical revelation. We have already noted that our understanding of God's creation needs to have the Old Testament picture completed by the New Testament's connecting of Christ with creation; it is even clearer that the New Testament's witness to this subject is thin compared with that of the Old Testament. Further, the Old Testament emphasises God's involvement and interest in the material, physical world. He is the Lord of the nations, is involved in world history, and is going to be active in the future bringing his will to full consummation. He has standards for the world and for men in such areas as sex and the family, property and work, and international relationships. In another direction, the Old Testament also provides much material for a pastoral theology of worship and prayer, of doubt and suffering and 'the dark night of the soul'. Kornelis Miskotte, Arnold van Ruler, and Ernest Wright have written particularly trenchantly of the importance of the Old Testament to a balanced

${ }^{30}$ Cf. T.C. Vriezen, An Outline of Old Testament Theology, Blackwell, Oxford (1958), 87 and n.3 ( 2 (1970), 100 and n.4).

Cf. J.L. McKenzie in Anderson, op. cit., 108-9. 
Christian theology which is to avoid 'Christomonism'.32

Old Testament and New Testament, then, belong together in the canon of Scripture. In a sense there can be no Old Testament theology, or rather it is a discipline without a raison d'être; and there can be no New Testament theology that omits all the New Testament's unspoken Old Testament presuppositions. There can in fact only be a biblical theology which cross-sections the whole canon. The standard Old Testament theologies take a step in this direction in that, as part of their Christian orientation, they often point out how Old Testament ideas find fulfilment in the New Testament. The step, however, is hardly enough - indeed it is a case of a little being worse than nothing, in as far as there is a danger of them losing the value of making clear the specific Old Testament witness, without properly showing how the total Old Testament and New Testament dovetail and complement each other. Pace Jacob, ${ }^{33}$ Old Testament theology will not be Christological; biblical theology will.

How this works with respect to the doctrine of creation has been hinted at: linking the testaments tells more about creation (because of the connection with Christ) and more about Christ (through the filling out of the idea of creation with which he is connected). One could apply it to the idea of law. The Old Testament provides many concrete indications of God's moral and social standards, but these are not systematized. The New Testament declares that all commandments hang on the love of God and one's neighbour. Linking the testaments, then, tells you the principles on which the Old Testament laws depend; it shows you how the generalizations of the New Testament might be itemized in one particular cultural situation. Or one could apply this to the idea of God's blessing. In the Old Testament this takes effect primarily in the material sphere (though the relationship of man to God is part of the covenant idea). In the New Testament God's blessings are primarily spiritual (though Jesus also declares that the material needs of those who seek the kingdom will

32 G.E. Wright, The Old Testament and Theology, Harper and Row, New York (1969) especially chapter 1; K.H. Miskotte, When the Gods are Silent, Harper and Row, New York (1967); A. van Ruler, The Christian Church and the Old Testament, Eerdmans, Grand Rapids (1971).

${ }_{33}$ E. Jacob, Theology of the Old Testament, Hodder and Stoughton, London (1958) 12. 
be met). Old Testament theology or New Testament theology alone might give a misleading impression of God's blessing. It would also be misleading to assume that the material concern of the Old Testament is on an inferior level compared with the spiritual concern of the New Testament God is God of both. Dietrich Bonhoeffer has laid particular emphasis on this: the Old Testament makes it especially clear that God claims the whole of life, that he is concerned with saving men for living in this life, and that it is precisely the man who loves life and the earth so much that without them everything would be gone, who really cares about the resurrection and the new world. ${ }^{34}$ "Where the ground bass (i.e. love for God) is firm and clear, there is nothing to stop the counterpoint (i.e. earthly love) from being developed to the utmost of its limits."35

\section{The function of theology}

But what is Old Testament theology (or biblical or dogmatic theology) for? Is there any reason why we should give in to the temptation to write it?

My colleague who teaches New Testament theology believes, predictably perhaps, that his discipline - or perhaps doctrine in a broader sense - is the most fundamental and central one in theology and should be given proportionately more time than others. Equally predictably, my response as a teacher of biblical studies is that exegesis and exposition should have the priority if anything. If doctrine were the most important thing, then the Bible would surely look more like a doctrinal manual, whereas form critically it does not resemble any creed or the Thirty-Nine Articles or a dogmatic theology. It is a collection of divine-human messages and responses in particular situations. It has a theology underlying it, no doubt, indeed a theology that is sometimes overt, but the cutting edge of God's message is not in the form of an abstract system but of a concrete message.

Thus the Christian's use of the Old Testament consists most importantly not in inferring the theology that underlies it but in extrapolating from its varied concrete messages to what may be God's message to our situation.

34 D. Bonhoeffer, Letters and Papers from Prison, Collins Fontana Books, London and Glasgow (1959) 50, 93-4, 112, 127.

${ }^{35}$ Op. cit., 100. 
But the function of theology is to aid this hermeneutical task. It does this both negatively and positively. Negatively, it protects us from mistaken interpretation. If an exegete suggests as the original meaning of an Old Testament passage something which seems to conflict with Old Testament or biblical theology, alarm bells ring. I put it no stronger than that; it may be that our grasp of biblical theology needs correcting. But alarm bells ring. Further, if an expositor suggests as the significance of a passage for today some message that seems to conflict with Old Testament or biblical or dogmatic theology, alarm bells will again ring. Again I put it no stronger than that: God may have some striking word to say to us that shatters our shallow understanding of scripture and enables us to see insights in the scriptural revelation that escaped us before. But alarm bells will ring. Thus theology helps us to test the spirits; to put it in more Old Testament terms, "the voice of the true prophet is always the voice of the law of God, once for all declared through Moses". ${ }^{36}$ Theology enables us to see passages in their total biblical context, and thus helps exegete and expositor to avoid eisegesis and imposition.

The whole area of the futurist interpretation of prophecy provides an example here. A straightforward, and thus attractive, interpretation of Ezekiel takes chapters of that book as a yet unfulfilled, or now being fulfilled, prophecy of the Israelites' return to Palestine, the rebuilding of the temple in Jerusalem, and so on. Yet when Israel, the land, and the temple, and indeed prophetic prediction itself, are seen within the context of a whole biblical theology, the 'straightforward' view is no longer possible.

Again, any kind of theology that 'lets the world set the agenda', any 'theology of praxis', ${ }^{37}$ runs the risk of misusing the Bible as a quarry for texts that enable one to share the world's insights, rather than to confront its misapprehensions: what Anthony Dyson calls "writing biblical-exegetical footnotes to secular paragraphs". ${ }^{38}$ Some would accuse Bon-

36 J.A. Motyer, 'Prophecy, prophets', in NBD, 1042a.

37 See, for instance, G. Guttierez, A Theology of Liberation, Orbis Books, Maryknoll, NY (1973), chapter 1. (Also S.C.M. Press, London, 1974).

38 A.O. Dyson, 'Dogmatic and Contextual Theology', S/E 29, Study Encounter $8: 3$ (1972), 6; cf. Wright, op. cit., 166. There is a notable embodiment of this by !Michael Novak in $\boldsymbol{A}$ Theology for Radical Politics (Herder and Herder, New York, 1969), which begins "I want to bring a radical Christian theology to the support of the student movement of the present generation" (17)! 
hoeffer as well as Harvey Cox of this technique. Here we are back to a pre-Gablerian relationship between the Bible and theology: the theology is first formulated and then the Bible foraged for proof texts independently of an attempt to understand the Bible in its own right.

An understanding of biblical theology as a discipline that is a positive aid for the expositor, providing the context for the contemporary interpretation of scripture, is expounded by Brevard Childs, in principle in Biblical Theology in Crisis and then in connected application in his commentary on Exodus. ${ }^{39}$ He suggests that Old Testament passages are to be seen in their total canonical context, in that we are to look at other passages where the one under discussion is quoted or its motifs alluded to, and also to go on to consider the history of the passage's interpretation, if we are to see how it is to be interpreted today.

Childs' treatment is full of insights. His principle, however, seems to me to be both too narrow and too broad. It is too narrow in that he confines the canonical context of a text to other passages where it is quoted or its specific motifs referred to. This has the merit of providing an objective control on alleged reinterpretation: there is a certain link between the various passages being brought into relationship. But the text's canonical theological context is much broader than merely the passages where it happens to be directly alluded to. Indeed the exegetical methods of the New Testament writers are ones that we will not necessarily expect to follow even though we can sympathetically understand them: it is the theological principles to which they give expression that will be our interest. ${ }^{40}$ And what of passages that are not referred to in the New Testament? ${ }^{41}$ Because of this limitation, in his commentary on Exodus Childs can offer no 'theological reflection' on chapters 15 or 17 or - more surprisingly, as it is used extensively in the New Testament - chapter 24.

Childs' approach is too broad in that he seems to place as

39 Opp. citt. in nn.10 and 29 above.

40 Cf. R. Longenecker, 'Can we reproduce the exegesis of the New Testament, Tyndale Bulletin 21 (1970), 3-38; see now his book-length treatment of these questions Biblical Exegesis in the Apostolic Period, Eerdmans, Grand Rapids (1974).

${ }^{41} C f$. Hasel, 'Methodology' 195. Childs does not in practice confine himself strictly to the actual quotation of a text elsewhere; see Biblical Theology in Crisis, especially the sample passages treated in Part III. 
much weight on postbiblical interpretation as he does on that within the canon, and in the end of the day to have a relativist idea of interpretation - a passage has no one meaning, it means many different things at different times.

Both of these faults, as I see them, are corrected by seeing passages more literally in the context of biblical theology, not just of (intra-) biblical exegesis. I offer two examples from the psalms. Psalm 42-43 is the lament of a man apparently in geographical exile from God's dwelling place in Jerusalem. But we do not locate God on this mountain or that, we have no pilgrim festivals to recall, no altar to return to: how can we use the psalm? Now New Testament echoes of it do appear on Jesus' lips on Palm Sunday (Jn. 12:27) and in Gethsemane (Mk. 14:34); these encourage us to link our sufferings to Christ's as we use the psalms. ${ }^{42}$ But broader help in seeing what is the equivalent Christian prayer to this lament is provided by seeing the idea of experiencing the presence of God in its context and diversity in biblical theology.

In both testaments this is a reality both of history and of worship. God is known once for all in the exodus and in the incarnation, but also here and now in the temple and in the gathering of believers in Christ's name (though note the differences in the latter case: the dwelling of God in the material temple is succeeded by a dwelling of God in a temple of the Holy Spirit, which is also the body of the Christ who spoke of his body as the temple and in whom all the fullness of the Godhead dwelt). There is under the old covenant a yearning for an experience of God which the exodus faith or the temple worship cannot satisfy (Ps. 42-43, Job, Ecclesiastes), a yearning in a sense fulfilled by the incarnation and giving of the Spirit, and yet at the same time one that the Christian believer will often also feel and which awaits final fulfilment in that heavenly Jerusalem which has no temple precisely because the dwelling of God pervades its whole.

Old Testament theology, or intra-biblical exegesis alone, will not help us to see what is the equivalent Christian prayer to this lament, but biblical theology will: the plea is for an experience of God's presence, which is granted historically in Christ, existentially in the Spirit, and eschatologically in

42 Cf. J.H. Eaton, Psalms (Torch Bible Commentaries), S.C.M. Press, London (1967), in loc. 
heaven. There may be times when God seems absent, forgetful, abandoning, dead; at such times we too may pour out our despair to God, as long as we go on to recall the objective realities of the faith and our personal experience of God's love and praise and prayer, and to plead with God for a new experience of Christ in his grace and truth coming out to fetch us and to lead us home to God's own presence. Then, in faith in the answering of this prayer, we may wait for God, and live in praise.

A second example of the need to see passages in their total biblical context if we are to interpret them aright might be kingship psalms - whether those that speak of Yahweh as king (e.g. 47) or of the earthly ruler (e.g. 45). These, I believe, were written in the pre-exilic period as statements of the present reality: Yahweh is king; his kingdom is in the hands of David. But the exile meant the deposing of the human king (an event threatened indeed by the institution's origin) and thus the apparent deposing of the divine king. The psalms from now on express not present belief but hope, of God really being king in the future (the imperfect tenses of Ps. 47 facilitate this), and of a branch to come forth from the stock of Jesse. Perhaps the assertions were recognized even before the exile as larger than life and implicitly eschatological. Anyway, the New Testament regards these hopes as fulfilled in Jesus ( $c f$. the actual quotations in Heb. 1: 5-9), though in a way that still leaves the consummation in the future. The psalms thus warn us about the nature of divine and human leadership, and about what must be the relationship between them, and point us to the model of it in Christ; they also show us what was the ideal of which he was the fulfilment, and whose final realization we still await. Not, of course, that we read this Christian meaning into the Old Testament text. We begin from historical exegesis. But then in the light of the total theological context of the Old Testament and New Testament we infer the function that the two psalms may fulfil now.

Not that the only valid exposition of a text is one that takes its cue from the final canonical context of a passage. There is a sense in which any passage contains the whole truth of God, applied to that particular situation, and therefore that it needs no other to interpret it. We can expound (though not exegete) Genesis 1 christologically, but we need 
not necessarily do so. Or consider the Song of Songs, a work similar to Psalm 45 in that it probably became canonical partly in connection with being interpreted messianically. Indeed, even if this is not the case, the utilization of the marriage relationship as an illustration of that between Christ and the church (Eph. 5) probably provides grounds for using the Song of Songs (or any good love poem) as a parable if not as allegory. And yet it must also be valid to treat it as an exposition of Genesis 2:24, so to speak: to follow its presumed original meaning as a poem about human love. ${ }^{43}$

Indeed the final canonical shape of the Old Testament is an unfortunate one which ought not to influence our understanding of it. The arrangement 'Torah-prophets-writings' separates off Genesis-Deuteronomy from Joshua, which really completes this great statement of the foundational salvation-history. It does this, no doubt, under the influence of the later postexilic law religion: Israel's foundation document is now predominantly law. ${ }^{44}$ And this is how the New Testament speaks of it, in response to current Jewish attitudes. But it is thereby perverted into legalism. Positive Christian exegesis of the pentateuch can go back to seeing it as gospel, or (to use its own term) as covenant.

To enable biblical theology to function hermeneutically in this way, it is necessary that it proceed by the cross-section approach, even though it will also need a historical/dynamic treatment of how different passages on the same subject interrelate.

Yet it is also true that the diachronic approach functions hermeneutically. For instance, we have seen that the creation theme in the Bible is applied in manifold ways. As we ask what in our historical context might this biblical idea have to say, the diversity of the biblical witness may not so much provide the actual content of our exposition as encourage the expositor to follow the Bible's example in applying the creation message to the particular concerns of the day. For instance, the fact that this is a created universe indicates that

43

\footnotetext{
D.J.A. Clines, in a paper on 'Expounding the Old Testament', suggests another example of this principle, namely the suffering servant passages in Isaiah 40-55. These, he submits, could be expounded without connecting them with Christ.

Cf. J.A. Sanders, Torah and Canon, Fortress Press, Philadelphia (1972), especially $1-15,47-53$.
} 
it has meaning - it is not the meaningless product of time plus chance; that it ought to be respected and looked after here is a theological basis for a concern about conservation; and that its resources are the common right of all men - here is a stimulus to work for a fair sharing of them.

Finally, one of the ways in which a fully biblical theology will aid preaching is by making us aware of operating with a canon within the canon. A biblical theology will incorporate the breadth of the message of scripture in the diversity of its emphases (though in turn exegesis helps biblical theology to to that: the relationship is two-way) and will indicate areas we do not take seriously. Of course it is right that particular aspects of God's truth will come home and be particularly important at different times in church history. But we have to do battle to avoid being imprisoned in what may have been the crucial insights of yesterday. And we need the whole Bible for that. 